Gerd-Helge Vogel

\title{
ARCHITECTURE FOR TEACHING, LEARNING AND RESEARCH: ACADEMIC ARCHITECTURE AT GERMAN UNIVERSITIES IN THE EUROPEAN CONTEXT FROM THE MIDDLE AGES TO THE ENLIGHTENMENT
}

THE EARly EUROPEAN UNIVERSITY: BOLOGNA, PARIS, AND

OXFORD DURING THE HIGH MIDDLE AGES - BUILDING PROTOTYPES FOR THE UNIVERSITAS EX CONSUETUDINE

The European university is known to have gradually developed from the various pre-existing church schools of medieval towns into guildlike associations of instructors and students (universitas magistrorum et scholarium). At certain stages in their evolution these institutions had to protect themselves against competing corporations like city councils, craftsmen's guilds, and religious orders which claimed similar rights. The academics defended themselves by asserting their teaching privileges in the fields of theology (religious beliefs), jurisprudence (Roman and Canonical Law), medicine (the studies of Galen and Dioscurides), the philosophy of Aristotle and - in the context of the studium generale - the seven liberal arts (septem artes liberales). Because the universities had been engaged in the dissemination of this knowledge for many years and argued that according to customary law it should remain their exclusive right, 
they requested official confirmation of their teaching privilege from the highest papal and imperial authorities.

The origin of this process goes back to the first three 'preuniversities' of Western Europe: the Bologna School of Jurisprudence (ca. 1088), the University of Paris later known as the Sorbonne (ca. 1150-1170), and the University of Oxford (ca. 1167-1180), whose international recognition, however, 'resulted less from privileges than from their successful endeavours'. ${ }^{1}$ From the very beginning, two evolutionary processes led to the creation of two very different university types: the scholastic school of Bologna (the Bolognese model) and the professors' university of Paris (the Parisian model). ${ }^{2}$ At the outset, the location of instruction and learning at these universities was not yet firmly established. Necessary for this was merely a room with a lectern like the reading or singing desk used in a church from which the gospel was preached (lectrum). For as long as no printed books with contents related to the curricula were available, scholastic lessons concentrated on the dictation of a lecture (lectio) copied down in writing by the students. The three aims in this process were: (1) to familiarize the students with the subject matter; (2) to enable them to remember it through repetition (repetitio); and (3) to practice the dialectic exercise of formally sustaining, attacking, and defending a thesis or an opinion (disputatio).

Notably, an inextricable connection between a scholastic lesson and an established architectural structure did not exist during this phase in the early history of European universities. Rather, there was a remarkable mobility in the selection of localities for lessons, living accommodation, and administrative rooms. In those days, public streets and squares, churches, or the professors' private homes frequently served as venues for scholastic lectures and seminar-like exercises. However, the survival of the universitas as an organization depended not only upon its structural framework comprised of a closed union of students and professors into an autonomous

1 Hans-Albrecht Koch, 'Semper reformanda! Acht Jahrhunderte europäische Universität', Architektur für Forschung und Lehre. Universität als Bauaufgabe, ed. by Klaus Gereon Beuckers (Kiel: Ludwig, 2010), 13-40, here 19.

2 See: Rainer A. Müller, Geschichte der Universität. Von der mittelalterlichen Universitas zur deutschen Hochschule (München: Callwey, 1990), 11; Franco Cardini, Mariateresa Fumagalli Beonio-Brocchieri, Universitäten im Mittelalter. Die europäischen Stätten des Wissens (München: Südwest, 2000), 46, 52; Stefan Fisch, Geschichte der europäischen Universität. Von Bologna nach Bologna (München: Beck, 2015), 13-14. 
association with a specific democratic organization. In the long term, universities needed some form of collective accommodation within an educational establishment as a permanent guarantee of reliable protection against outside authorities.

Despite the aforementioned flexibility in choosing locations, the only really effective way to teach students and ensure a suitable atmosphere for their acquisition of knowledge was to house the necessary facilities in a building dedicated exclusively to lecturing and residence. But because the educational establishments were usually provided by town municipalities, generous donor-patrons, or ruling authorities, there emerged interdependencies between universities and their founders with a special respect for the latter's financial support of the institution, their claim to exert influence on the appointment of teaching positions, or expectations to be given perpetual credit for the reputation of what they regarded as their own universities. These dependencies frequently threatened to undermine the cooperative freedom and independence of the universities. ${ }^{3}$ In some cases, the only effective means of maintaining the teachers' and students' collective autonomy was to apply coercive pressure, i.e., to announce the complete exodus of all university members from a town. This measure was not only employed against host communities in the early days, but also in later years when universities disenchanted with their previous locale were re-established as so-called 'exodus universities' (Auszugsuniversitäten) in towns or residences promising them their academic rights and privileges under solid guarantees. ${ }^{4}$

The archetypal European university edifice as a place for the dissemination of education and knowledge was represented by the college building (Kollegiengebäude), ${ }^{5}$ which derived from earlier monastery-like structures where teachers and students lived together as a single, consolidated community. Initially, board and lodging for poor students formed the basis for the founding of such college buildings. From the late $12^{\text {th }}$ century onward, however, due to the increasing goal-oriented organization of the curricula, the

3 Wolfgang Eric Wagner, Universitätsstift und Kollegium in Prag, Wien und Heidelberg. Eine vergleichende Untersuchung spätmittelalterlicher Stiftungen im Spannungsfeld von Herrschaft und Genossenschaft (Berlin: Akademie Verlag, 1999).

4 Koch, 'Semper reformanda! Acht Jahrhunderte europäische Universität', 21.

5 Konrad Rückbrod, Universität und Kollegium, Baugeschichte und Bautyp (Darmstadt: Wissenschaftliche Buchgesellschaft Darmstadt, 1977). 
colleges eventually developed into more full-fledged educational institutions. In addition to the living-quarters reserved for teachers and students, colleges offered the members of the universitas - who were organized into faculties and nationalities - extra space to be used for classrooms, prayer-rooms, the library, and the refectory. Examples of early collegiate structures in Paris were the Collège des Dix-Huits (1180), ${ }^{6}$ the Collège de Sorbonne (1257-1283), ${ }^{7}$ and the Collège de Navarre (1304). ${ }^{8}$ In their architectural design and construction, these colleges resembled dignified town houses. ${ }^{9}$ Yet owing to their semimonastic lifestyle, tutors and students strove to take over whatever former monasteries and residences that were available in the town. Since they preferred cloister-like buildings with a chapel and an interior courtyard, which provided an atmosphere of seclusion, such elements were also included in any newly built colleges.

'In Paris, at least fifty colleges were created between the years 1300 and $1500,{ }^{\prime 10}$ and since they were privately founded, they were widely scattered throughout the urban environment. In subsequent years, however, they were concentrated into what is known as the Quartier Latin. This was a district where the colleges could offer the architectural facilities needed for scholastic instruction in the four faculties of theology, jurisprudence, medicine, and the arts, all of which were determined by the dogmas and beliefs of the Christian faith. Thus, in this milieu, the scholastic form of instruction and education produced a type of scholar who employed his extensive knowledge and erudition to confirm the unshakable truth of divine revelation and who had very little in common with the research scholar of our own times. ${ }^{11}$

6 Hastings Rashdall, The Universities of Europe in the Middle Ages, vol. 1. Salerno-BolognaParis (Oxford: Oxford University Press, 1936), 501-502; Rückbrod, ibidem, 40.

7 Rashdall, ibidem, 507-509; Rückbrod, ibidem, 44-49.

8 Rashdall, ibidem, 510-511.

9 Ernst Badstübner, 'Architektur für Bildung und Wissenschaft. Universitätsbauten in Vergangenheit und Gegenwart', Das steinerne Antlitz der Alma Mater. Die Bauten der Universität Greifswald 1456-2006, ed. by Michael Lissok, Bernfried Lichtnau (Berlin: Lukas-Verlag, 2006), 14.

10 Cardini, Beonio-Brocchieri, Universitäten im Mittelalter. Die europäischen Stätten des Wissens, 61.

11 Rudolf Kötter, 'Vormoderne und moderne Universität - Berufsschule, Bildungsanstalt oder Hort der Wissenschaft', Akademie und Universität Altdorf, ed. by Hanns Christof Brennecke, Dirk Niefanger, Werner Wilhelm Schnabel. Studien zur Hochschulgeschichte Nürnbergs (Köln: Böhlau Verlag, 2011), 438-440. 
To summarize, one can state that, as a rule, 'the medieval university, as an institutional entity, did not yet exist: it merely formed ... a frame of reference for its subunits (Teileinheiten), a state already evident in the scattered distribution of its buildings throughout the urban townscape. University students were accommodated in the houses of masters or professors, in hostels, colleges, or faculties, and - if available - in buildings of the university`s various nations. They were members of one or more of its subunits without necessarily being incorporated members of the university as a whole'. ${ }^{12}$ This circumstance explains both the unique 'landscape' of medieval universities in their close interrelationship with the surrounding town and their demand for obtaining a more concentrated architectonic complex placed within one particular district of a town.

Initially, the indigenous form of English universities like Oxford and Cambridge was not fundamentally different from that of the Parisian prototype. However, with the inclusion of dormitories, residence halls, or hostels (where the students paid rent to live with their professors who simultaneously served as their tutors), a new form of university was created in England. Along with colleges founded as monastery-like boarding schools, (where the university lectures and seminars were also held), a campus-type model also evolved as another particular sort of university. ${ }^{13}$ Moreover, its location on the periphery of the town allowed for that growing need for space brought about by the on-going development of further educational requirements and the ever-increasing numbers of students and academic staff.

GERMAN UNIVERSITIES AS ACADEMIC COOPERATIVES AND EDUCATIONAL INSTITUTIONS: FROM THE FIRST PHASE OF INSTITUTIONS FOUNDED BY LOCAL RULERS UNTIL THE END OF THE MIDDLE AGES

All the seventeen medieval universities founded on German imperial territories followed the Parisian model and are classified as civic or princely foundations. In this period, for instance, it began with the Charles University established at Prague in 1348 by King Charles

12 Wagner, Universitätsstift und Kollegium in Prag, Wien und Heidelberg, 23.

13 Rückbrod, Universität und Kollegium, Baugeschichte und Bautyp, 53-55; Müller, Geschichte der Universität, 37-38; Cardini, Beonio-Brocchieri, Universitäten im Mittelalter, 64. 
IV of Bohemia and ended with the Alma Mater Viadrina at Frankfurt on the Oder set up by Elector Joachim I of Brandenburg in 1506. ${ }^{14}$ The same is true for the adoption of the Collegium as a building for teaching and living-quarters, as it was realized at Prague's Collegium Carolinum dating from the year $1366,,^{15}$ and the Collegium Ducale at Vienna founded by Duke Albrecht III in 1384 which was to house twelve masters of the arts (Artistenmagister) and one or two theologians. ${ }^{16}$ At the same time, this offered teaching and faculty rooms for professors and students of the arts, medicine, and theology; could be equipped with a chapel, a library, and an assembly hall; and enjoyed the advantage that important, university administrative functions might be also integrated into the building. ${ }^{17}$ Colleges that were structurally comparable were built later during the first and second phase of university foundations in Germany (ca. 1348-1400 and 1450-1506). Among those, for example, were the Major and Minor Colleges established at Leipzig by the two Margraves of Meissen in Saxony - Frederick and William - after models like the Charles and Wenceslaus Colleges at Prague's Charles University. The 'exodus university' at Leipzig was established very quickly in order to accommodate German professors and students from Prague who had fled from the unfair social, political, and administrative changes that had come about after the death of Emperor Charles IV. ${ }^{18}$ And again, at Erfurt University - the Hierana - erected a Collegium maius in 1511-1515 as an edifice with the same sort of multifunctional design to replace its predecessor the Collegium universitatis (dating from 1434), which had been destroyed by student unrest on 4 August $1510 .{ }^{19}$ During

14 This situation applies to: the universities of Prague (1348), Vienna (1365), Heidelberg (1385), Cologne (1388-1798), Erfurt (1392-1816), Würzburg (1402-1413), Leipzig (1409), Rostock (1419), Greifswald (1456), Basel (1460), Freiburg/Breisgau (1460), Ingolstadt (1472-1800), Trier (1473-1798), Mainz (1477-1798), Tübingen (1477), Wittenberg (1502-1817), and Frankfurt/Oder (1506-1811). See: Thomas Ellwein, Die deutsche Universität vom Mittelalter bis zur Gegenwart (Frankfurt am Main: Hain, 1992), 321-322.

15 Wagner, Universitätsstift und Kollegium in Prag, Wien und Heidelberg, especially 44-45.

16 Ibidem, 106-110.

17 Rückbrod, Universität und Kollegium, Baugeschichte und Bautyp, 109-110.

18 Beate Kusche, Henning Steinführer, 'Die Bauten der Universität Leipzig von 1409 bis zum Beginn des Dreissigjährigen Krieges', Geschichte der Universität Leipzig 1409-2009, Bd. 5. Geschichte der Leipziger Universitätsbauten im urbanen Kontext, ed. by Michaela Marek, Thomas Topfstedt (Leipzig: Leipziger Universitätsverlag, 2009), 11-50, here especially 14-25.

19 Walter Blaha, Josef Metze, Kleine illustrierte Geschichte der Universität Erfurt 1392-1816, Bd. 4. Erfurter Chronik (Erfurt: Verlagshaus Thüringen, 1992), 9, 91. 
this period, we also observe a trend toward more prestigious college buildings. They were no longer meant to merely display the national or faculty-specific parts of colleges. Instead, the entire university was seen as one complete, self-contained teaching institution. It embodied the entire spectrum of scholastic erudition (universitas litteraria) and was to allow for the increasingly influential movement of humanism with its broadening array of subjects in the faculty of arts and, indeed, to emphatically present the institution itself as one, impressive educational entity. The arbitrary (and not infrequently accidental) distribution of university buildings throughout towns resulting from the ongoing 'partial foundings' (Teilstiftungen) mentioned above, proved counterproductive to the aim of integrating all faculties into a single university. This state of affairs led to the institution's provisional installment within various municipal districts where in the majority of cases - existing buildings were renovated and then put into academic use. ${ }^{20}$ This procedure explains, to some degree, the continuing de-centralized location of buildings like hostels, colleges, collegiate churches, etc. within the organism of medieval university towns in Germany, although for functional reasons a decidedly localized focus of university institutions was still attempted. Thus, in Latin Quarters a certain amount of concentration was achieved, among others, at Heidelberg's Ruperto Carola, where the former Jewish ghetto was made available for the establishment of the majority of the university's buildings. ${ }^{21}$ Similar concentrations of buildings in one place, to name only a few, can be observed at the Hierana at Erfurt, ${ }^{22}$ the alma mater at Leipzig, ${ }^{23}$ the Gryphica at Greifswald, ${ }^{24}$ and the Leucorea at Wittenberg. ${ }^{25}$

20 Rückbrod, Universität und Kollegium, Baugeschichte und Bautyp, 106.

21 Gerhard Ritter, Die Heidelberger Universität. Ein Stück deutscher Geschichte, Bd. 1. Das Mittelalter (1386-1508) (Heidelberg: Carl Winter, 1936), especially 135-139; Hastings Rashdall, The Universities of Europe in the Middle Ages, vol. 2. Italy-Spain-France-Germany-Scotland (Oxford: Oxford University Press, 1936), 252-253; Rückbrod, Universität und Kollegium, Baugeschichte und Bautyp, 111-112.

22 Rashdall, ibidem, 249; Blaha, Metze, Kleine illustrierte Geschichte der Universität Erfurt, 11; Almuth Märker, Geschichte der Universität Erfurt 1392-1816 (Weimar: Böhlau, 1993), 27-29.

23 Kusche, Steinführer, 'Die Bauten der Universität Leipzig von 1409 bis zum Beginn des Dreissigjährigen Krieges', especially 20-25.

24 Das steinerne Antlitz der Alma Mater. Die Bauten der Universität Greifswald 1456-2006, ed. by Michael Lissok, Bernfried Lichtnau (Berlin: Lukas, 2006), especially 116-118.

25 Kathrin Ellwart, Die Universität Wittenberg. Gründungsphase und bauliche Ausstattung. Studienarbeit (München: GRIN Verlag, 1990), 9-14. 


\section{HUMANISM AND CONFESSIONALISM DURING THE EARLY MODERN PERIOD}

Along with the increasing power of certain rulers and the parallel, territorial fragmentation of the German Empire, there was an increase in the demand for academically trained civil servants who were to fulfill official, administrative tasks as clergymen, judges, medical doctors, and professors. Likewise, many princes and sovereigns strove for more power and wished to display their preeminence and influence by founding a university and thereby gain more independence from the schism-plagued Papacy and the diminishing power of the Holy Roman Emperor. Furthermore, on the eve of the early modern era - with its influx of Humanism from Italy that revived ancient art, literature, and philosophy - the scholastic method for teaching and disseminating knowledge gradually lost its significance. Rulers who wanted to extend their sphere of influence could appoint salaried professors to the regional universities they had founded in their own states. This practice frequently undermined the once-secure academic rights and freedoms most educational institutions had previously enjoyed. Beginning in 1517, with the spread of the Reformation and the aversion of its adherents to the semi-monastic organization of colleges, students moved out of the university hostels, rented their own private quarters, and increasingly participated in the daily life of the town. The new theological, humanistic, and scientific curricula simultaneously altered university life; something that is most clearly manifested by the eleven Protestant universities established during the third phase of foundation in the age of the territorial states. It began with the Philippina at Marburg in 1527 and ended with the Christiana Albertina at Kiel in $1665 .{ }^{26}$ Some universities like Marburg's Philippina or Jena's Salana (founded 1558), ${ }^{27}$ moved into

26 Protestant universities from this period: Marburg (1527), Königsberg (1544), Jena (1558), Helmstedt (1574), Altdorf (1578), Herborn (1584), Giessen (1607), Rinteln (1620), Strassburg (1621), Duisburg (1655), Kiel (1665). See: Müller, Geschichte der Universität, 55.

27 There was sufficient space in the former Dominican monastery for the Collegium Jenense and its collegiate church, the assembly halls (Auditoria) for the four faculties, the senatorial conference room (Consistorium), the rooms for the natural sciences and art collections (Musea), the court (Area), the university detention room, student hostel, the observatory (Observatorium), the library, inspector's house, and the Hortus medicus up until the mid-18 ${ }^{\text {th }}$ century. At this time, an anatomical theatre was installed in the ruins of the southwest corner of the town's medieval fortifications when an expansion of the university land-area was being undertaken. See: FranzJoachim Verspohl, Rudolf Ziessler, Jenaer Universitätsbauten [Minerva. Jenaer Schriften zur Kunstgeschichte, Bd. 1] (Gera: Arnstadt. Druckhaus Gerna, Rhino-Verlag, 1995), 12-16. 
secularized Dominican monasteries, which provided ample space for a comparatively limited number of students, ${ }^{28}$ and therefore permitted the accommodation of practically all the required university facilities 'under one roof'. This state-of-affairs illustrates once again the trend, mentioned above, towards the concentration of functions within a single, central building. Associated with this development of establishing and endowing a main edifice was the sovereign's dual intention of promoting the Universitas litteraria and presenting himself as a patron of learning. This applies especially to the Altorfina at Nürnberg (1578), ${ }^{29}$ and the Julia Carolina at Helmstedt (1576), ${ }^{30}$ where new buildings added a special character to the universities. Yet the design of such colleges with their buildings grouped around an interior courtyard - echoing the cloister of monasteries - was still employed and the monumental, representative designs of these building-complexes were, nevertheless, often patterned after urban palaces, princely residences, and civic town halls.

This same trend can be observed in the ten, newly founded universities in Catholic regions, ${ }^{31}$ which were erected primarily by the Jesuits. After the Counter-Reformation resolutions were concluded at the Council of Trent (1546-1563), a more direct orientation towards Roman prototypes came to the fore. In Rome, under the pontificate of Pius IV (1559-1565), a new university, the Sapienza, was designed by the architect Francesco Borromini and built between 1575-1660. Here, an overall quadrilateral design consisting of three wings, each three and a half floors high, with an inner courtyard surrounded by two-storied

28 In 1531-1535, Marburg's university had on average 401 students per year, which later was reduced by half, to 210, during the years 1540-1620. Compare: Franz Eulenburg, Die Frequenz der deutschen Universitäten von ihrer Gründung bis zur Gegenwart (Leipzig: B.G. Teubner, 1904), 54, Tab. 2; 84, Fig. 4. In this same period, Jena had an average student body of 403 per year and counted as the sixth largest university after Wittenberg, Leipzig, Helmstedt, Frankfurt, and Ingolstadt.

29 See: Matthäus Merian, Topographia Germaniae. Das ist vollkömliche Beschreibung und eygentliche Abbildung der vornehmbsten Städte und Oerther. Vol. Bayern, Franken (Frankfurt: [s.n.], 1656), 20-21; Georg Andreas Will, Geschichte und Beschreibung der Nürnbergischen Universität Altdorf. Zweite Ausgabe mit Nachträgen von Christian Conrad Nopitzsch (Altdorf, 1801; reprint Aalen: Scientia Verlag, 1975), 154-211.

30 See: Matthäus Merian, Topographia Germaniae. Das ist vollkömliche Beschreibunf und eygentliche Abbildung der vornehmbsten Städte und Oerther. Vol. Braunschweig, Lüneburg (Frankfurt: [s.n.], 1654), 113-115.

31 These Catholic universities were: Dillingen (1549), Würzburg (re-founded in 1582 after its initial establishment in 1410), Graz (1586), Paderborn (1615), Salzburg (1623), Osnabrück (1630), Bamberg (1648), Innsbruck (1675), Breslau (1702). See: Müller, Geschichte der Universität, 57. 
loggias, is enclosed by the university church of St Ivo. ${ }^{32}$ The monumental palace-like building offered generous space for teaching, assembly, and administration rooms, including accommodations for professors and students, thus 'exemplifying the adaptation of this building-type for a university'.$^{33}$ From the mid $-16^{\text {th }}$ to the early $18^{\text {th }}$ centuries, German Catholic universities influenced by these Roman prototypes continued to build palace-like universities with connections between a church, living spaces for professors and students, lecture halls, and working quarters. Beginning with Dillingen (1549), and followed by Würzburg's Julius University (1582), ${ }^{34}$ the trend was maintained until the foundation of Breslau's Leopoldina (University of Wrocław) in 1702, thus manifesting the adherence to monastery-like boarding school buildings, although 'the majority of the students remained externi [i.e. resided outside the university]'. ${ }^{35}$ An example that the four-wing plan was not always regarded as mandatory is demonstrated by the Leopoldina in Breslau. The extended, multi-storied facade of the building with its many bays, which is still recognizable as a college, displays a modified type derived from Baroque palace architecture. To increase the impressive effect of such a 'palace of learning' (Palast des Wissens), ${ }^{36}$ the symmetrical design is emphasized either by the creative elaboration of the central bay crowned with a monumental tower like in Breslau, or, more simply, with a triangular pediment placed above a slightly prominent bay as was chosen for the Mayersche Collegium (1750) at Greifswald University by professor Andreas Meyer, who designed an overall university edifice 'copying Swedish-Pomeranian manor-house prototypes.' ${ }^{37}$

32 Compare: Rückbrod, Universität und Kollegium, Baugeschichte und Bautyp, 136-137; Jörg Stabenow, 'Die Universität als Palast? Zur typologischen Identität der frühneuzeitlichen Universitätsarchitektur in Italien', Architektur für Forschung und Lehre. Universität als Bauaufgabe. Beiträge zur Tagung des Kunsthistorischen Instituts der Christian-AlbrechtsUniversität zu Kiel am 5. bis 7. Juni 2009, ed. by Klaus Gereon Beuckers (Kiel: Ludwig, 2010), 57-89, here 79-83.

33 Rückbrod, Universität und Kollegium, Baugeschichte und Bautyp, 134.

34 Merian, Topographia Germaniae. Das ist vollkömliche Beschreibung und eygentliche Abbildung der vornehmbsten Städte und Oerther. Vol. Bayern, Franken, 112; Rückbrod, Universität und Kollegium, Baugeschichte und Bautyp, 139-140.

35 See: Müller, Geschichte der Universität, 55-56.

36 Architektur für Forschung und Lehre. Universität als Bauaufgabe, 8.

37 Mayer, who was originally from Augsburg, created a plan to replace the former Kollegium housed in the Ernst-Ludwig-Bau. This building was demolished in 1747. See: Badstübner, 'Architektur für Bildung und Wissenschaft. Universitätsbauten in Vergangenheit und Gegenwart', 20; compare also Das steinerne Antlitz der Alma Mater. Die Bauten der Universität Greifswald 1456-2006, 136-140. 


\section{UNIVERSITIES AS 'SCHOOLS FOR CIVIL SERVANTS' DURING THE AGE OF ABSOLUTISM AND THE EARLY ENLIGHTENMENT}

During the age of Absolutism, when German universities functioned primarily as schools for civil servants (Staatsdienerschulen), ${ }^{38}$ an increasing contradiction emerged between the Baroque form of education employing late scholastic and humanistic methods and the new enlightened scientific approach based on rational thinking and empirical epistemology. While adherence to old authorities led to dogmatism and fossilized methods of learning, the 'reformed universities' (Reformuniversitäten) sowed seeds of intellectual renewal that provided credence to the principle of Libertas philosphandi or freedom of thought, teaching, and learning. ${ }^{39}$ In addition to the Academia Salana at Jena - where mathematical and natural science approaches had already been able to successfully establish themselves in the second half of the $17^{\text {th }}$ century - an intellectual rejuvenation also took root in the newly founded Salina or Alma Mater Halensis set up in 1692 by the Elector Frederick III of Brandenburg at Halle on the Saale. In fact, the Alma Mater Halensis became not only the most popular German university during the first half of the $18^{\text {th }}$ century, but even evolved into a center of the early Enlightenment with an influence resonating well beyond the borders of German-speaking lands. Its reputation and prestige owed primarily to: the lawyer Christian Thomasius, who secured a place for the role of natural law (Naturrecht) in the curriculum and for German as the primary language for academic teaching; the theologian August Hermann Francke, who was a major proponent of Pietism; and the mathematician Christian Wolff, who established rationalist thinking as the obligatory scholarly standard. During the second half of the $18^{\text {th }}$ century, this chief function as leading university was fulfilled by the Georgia Augusta University at Göttingen founded by Elector Georg August of Hanover in 1734. Georg August, who also ruled the British Empire in personal union as King George II in London, appointed his minister Gerlach Adolph von Münchhausen - a man educated at Jena and Halle - as the first curator of Göttingen University. Münchhausen served as a driving force in the process of founding this institution

38 Ellwein, Die deutsche Universität vom Mittelalter bis zur Gegenwart, 47-52.

39 Fisch, Geschichte der europäischen Universität. Von Bologna nach Bologna, 34-35. 
and it was to remain the most modern of its kind in Germany until the opening of the Berlin University in 1810. Thanks to the close political interconnections with England, the University of Göttingen functioned as a key gateway for many modern ideas.

That a novel 'ideal university landscape' was not immediately required in order to achieve new patterns of academic thought is shown precisely by our example of the University of Halle, which lacked its own university building until the year 1834. Between 1734 and 1834 it had to be content with using the municipal 'Weigh House' (Städtische Waage) as its assembly hall, the professors' private apartments for the majority of lectures and seminars, and a few rooms in the residence palace (Residenzgebäude), before a new representative main building and some additional ones for the departments of the new natural sciences were available. At Göttingen's Georgia Augusta, the dilapidated Pauline Monastery of the Dominicans with its imposing, towerless church functioned as the architectural basis for a new collegiate house (Kollegienhaus), that gave accommodation for all the faculties and apartments for some professors. ${ }^{40}$ Since it was the policy of the new alma mater to attract mainly wealthy, aristocratic students, it became necessary to offer subjects for cavaliers (Kavaliersfächern) such as riding, fencing, dancing, hunting, and modern foreign languages. Similar to the knights' academies (Ritterakademien) typical of the period, the aristocratic studiosus was to be cultivated into a perfect courtier, un homme gallant by masters specialized in these fields. ${ }^{41}$ Accordingly, the accomplishment of lessons in these courtly exercises (höfischen Exercitia) required suitable buildings to be constructed such as Göttingen University's riding academy (1734-1736) and fencing rooms (1742) in which these social disciplines could be taught and practiced. Constructed one after another from 1739 until 1816 were the department buildings for the expanded modern schools of medicine and natural science. ${ }^{42}$ They were built to keep pace with the rapidly growing need for the natural sciences which had established themselves as autonomous disciplines after being emancipated from the faculty of medicine. The enormous expansion in knowledge during such a short time-span, the

40 Alfred Oberdiek, Göttinger Universitätsbauten. 250 Jahre Baugeschichte der GeorgAugust-Universität (Göttingen: Göttinger Tageblatt, 1989), 9-11, 13.

41 Müller, Geschichte der Universität, 63.

42 Dealt with in more detail by: Oberdiek, Göttinger Universitätsbauten. 
creation of special disciplines employing various research methods, and the urgently needed new research equipment, resulted in a shortage of space that no longer allowed total accommodation within one individual university building. Consequently, around the year 1800, universities defined themselves more and more as institutions for teaching and research and began to renew their integration into the organism of their local towns. Thus forming, once again, that scattered 'university landscape' which had existed during the Middle Ages. In addition, throughout the course of this development, the constraints caused by old, medieval town walls were frequently removed - as it happened at Göttingen. Those open areas of land previously located beyond the now-demolished fortification walls facilitated the construction of additional buildings for more university departments.

A similar development took place in 1802 with the re-founding of the University of Tartu (Dorpat) located on the periphery of German cultural influence. Here, the Russian Emperor Alexander I created a modern institution which served as a prototype for his entire Empire and was to assist this huge country in its future development according to Western and Central European models. The main impetus behind the organization and arrangement of the Alma Mater Dorpatensis was her founding rector Georg Friedrich Parrot, who, along with Karl Morgenstern, Johann Wilhelm Krause, and other competent men of the 'Plantations' - or university landscape commission, pursued a Neoplatonic ideal aimed at creating an enlightened teaching and research institution. Parrot wished to create a university inspired in both its physical form and curricula by ancient Greek teaching institutions like the grove of Plato's Academy, ${ }^{43}$ and Zeno of Kiton's Stoa Poikile at the Athenian agora. They served as 'guiding lights' to emulate so that Dorpat (Tartu) University could become a true 'Athens on the Embach'. Karl Morgenstern suggested a revival of the instruction and scholarly disputation within a shady grove, 'an idea which G. F. Parrot took up, as he carried through the proposal for the planting of Dorpat's cathedral hill with trees as the center of the academic campus'. ${ }^{44}$ The

43 Compare: Gerd-Helge Vogel, 'Johann Wilhelm Krauses Entwürfe für eine Badeanstalt in "Embach-Athen" und das Ideal einer platonischen Republik', Baltic Journal of Art History, 3 (2011/2012), 353-372, here 351-356.

44 Ibidem, 354. No. 91. Protocol from the Rentkammer dated 30 November 1803. Extract from a protocol of the Council of the Imperial University of Dorpat dated 17 October 1803. National Archives of Estonia [Rahvusarhiiv, RA, EAA], 402.6.521, unpaginated. 
result was Johann Wilhelm Krause's 'university in the park' which was suited for Dorpat's numerous institutional facilities of modern sciences. ${ }^{45}$ At the same time, by applying a neoclassical design, Krause evoked the idea of an antique Temple of Science (Tempel der Wissenschaft) with its imposing main university building, whose multifunctional structure in the form of a college permitted the integration of the administration, the assembly hall, the teaching and meeting rooms, and student detention cells. The ground plan, side, and front elevations of Krause's Temple of Science truly owe much to the Palladian tradition of a Baltic villa rustica, i.e. a rural villa or country manor house. ${ }^{46}$ But the splendid portico with its six monumental Doric columns harks back to the architectural element of a columned hall as found at the Athenian Agora. Krause's architecture symbolically represented the philosophical school of the Stoa ${ }^{47}$ which fundamentally believed in a divine principle of reason or Logos - something thought to have penetrated nature's totality - and a premise that was fully embraced by Enlightenment-era philosophers.

By the Napoleonic period, except for several German reform universities like Göttingen, Halle, Jena, and Erlangen (from 1743 onward), approximately 45 universities in German-speaking, patchwork principalities suffered a severe crisis resulting from intellectual stagnation, inefficiency, diminishing student numbers, ${ }^{48}$ and an unnecessary competitive pressure caused by a 'surplus of university foundations' (Übergründungen) in numerous minor territories that were established merely from a yearning for prestige ${ }^{49}$ The crisis in academic life evident everywhere had begun during the Ancien Régime and

45 Johann Wilhelm Krause 1757-1828, kataloog 3: linnaehitajana Tartus = Als Stadtbauer in Tartu, ed. by Juhan Maiste, Anu Ormisson-Lahe (Tartu, Tallinn: Tartu Ülikool, Eesti Keele Sihtasutus, 2011), especially 15-55; Juhan Maiste, Kadi Polli, Mariann Raisma, Alma Mater Tartuensis: Tartu Ülikool ja tema arhitekt Johann Wilhelm Krause (Tallinn: Eesti Keele Sihtasutus, 2003).

46 Maiste, Polli, Raisma, Alma Mater Tartuensis, 183.

47 Bernhard Schäfers, 'Die Universität als Lehrgemeinschaft. Soziologische Anmerkungen über ihren Wandel und ihre Architektur', Architektur für Forschung und Lehre. Universität als Bauaufgabe, ed. by Klaus Gereon Beuckers (Kiel: Ludwig, 2010), 41-55, here 42-43.

48 In comparison to previous years, when student enrolment was significantly higher, the average number of students matriculating at all German universities from 1796 to 1800 was only 14,721. Eulenburg, Die Frequenz der deutschen Universitäten von ihrer Gründung bis zur Gegenwart, 162-163, Tab. V.

49 Eike Wolgast, 'Phönix aus der Asche? Die Reorganisation der Universität Heidelberg zu Beginn des 19. Jahrhunderts', Heidelberg im säkulären Umbruch: Traditionsbewusstsein und Kulturpolitik um 1800, ed. by Friedrich Strack (Stuttgart: Klett-Cotta, 1987), 35-60, here 35. 
eventually caused the extinction of numerous universities, ${ }^{50}$ including even old and venerable institutions like those at Cologne, Altdorf, and Erfurt. The main reason for this state-of-affairs was that their academic programs still persisted in being primarily based upon outdated forms of educational instruction rather than on new methodologies. These modern methods were concentrated on increasing knowledge via a close interconnection with applied experience, i.e. theoria cum praxi, as the acknowledged principle of teaching and research, which had established itself in the meantime in academies, scholarly societies, and at special professional colleges (Spezialhochschulen), ${ }^{51}$ where the rules of a 'practical, technically usable, and profitable science had long been applied'. ${ }^{52}$

\section{UNIVERSITY TEACHING AND RESEARCH IN THE 19 CENTURY: LIBERALISM AS A PREREQUISITE FOR ACADEMIC ADVANCEMENT}

After defeat in the struggle against Napoleon, Prussia strove to compensate for its lost competence in military and political spheres by improving education. The founding of the University of Berlin, in 1810, with its explicit emphasis not only on educating students from the province of Prussia - but from all over Germany - seemed an excellent means to reach this goal. Under the influence of the

50 Compare: Günter Steiger, 'Brotgelehrte und Philosophische Köpfe', Magister und Scholaren, Professoren und Studenten. Geschichte deutscher Universitäten und Hochschulen im Überblick, ed. by Werner Flaschendräger, Werner Klaus, Roland Köhler, Aribert Kraus, Günter Steiger (Leipzig: Urania-Verlag, 1981), 76-77. The dying out of universities began with the closings of the University of Bützow (1789) and the University of Stuttgart (1794), the latter had only been founded thirteen years earlier. In 1797-1798, the French occupation of regions on the left bank of the Rhine River caused further closings that occurred in Bonn, Cologne, Mainz, and Trier. This culminated in the transferral of the Landesuniversität Ingolstadt as well as the liquidation of the Catholic schools of higher education at Bamberg, Dillingen, and Fulda between 1803 and 1807, but also continued with the closing of universities at Helmsted, Altorf, Rinteln, and Paderborn in 1809. Then, Innsbruck and Salzburg followed in 1810, while Frankfurt/Oder and Breslau merged in 1811. In 1816-1817 Erfurt, Herborn, and Wittenberg (consolidated into the University of Halle) all closed. Finally, in 1818, this period of decline for German universities came to an end with the dissolution of Duisburg University and the conversion of Münster University into a theological/philosophical teaching institution.

51 For example, the founding of the mining academies in Freiberg (1769) and Berlin (1770), and also the veterinarian schools in Dresden (1774), Hanover (1778), Berlin and Munich (1790) among others.

52 Werner Flaschendräger, 'Vernunft contra Autoritäten', Magister und Scholaren, Professoren und Studenten. Geschichte deutscher Universitäten und Hochschulen im Überblick, ed. by Werner Flaschendräger, Werner Klaus, Roland Köhler, Aribert Kraus, Günter Steiger (Leipzig: Urania-Verlag, 1981), 62. 
philosopher Johann Gottlieb Fichte and the theologian Friedrich Daniel Schleiermacher, among others, the political scientist Wilhelm von Humboldt drafted a sound, future-oriented conception for the new university's constitution which, from the view point of a comprehensive school-reform, considered the entire educational system to be an organic whole focusing upon the universitas litterarum as being the final and highest level in the program. ${ }^{53}$ In this way, the new Berlin University 'was assigned the task of the general education of mankind' which could only be achieved through 'the "pure idea of science", i.e. philosophy, and the solitude and freedom necessary for its acquisition. ${ }^{54}$ Therefore, it was, for the time being, enough to relinquish the Prince Henry Palace in Berlin (1810) or the Residence Palace in Bonn (1818) to provide for 'the reform ideas emphasizing inner values that needed somewhat more than simply the outer shell. ${ }^{55}$ Only through these prerequisites could the future university landscape freely develop according to its scholarly requirements. ${ }^{56}$

\section{ThE ROyal STATE AgRiCUltural ACADEMY IN ELDENA - THE CREATION AND FAILURE OF A MODEL UNIVERSITY LANDSCAPE FOR THE PRUSSIAN ENLIGHTENMENT ${ }^{57}$}

Around 1800, the importance of efficient, capitalistic agricultural production received greater recognition from the Prussian state. In this field, England had already made great inroads. An important role in bringing about Prussia's awareness of these developments was

53 Steiger, 'Brotgelehrte und Philosophische Köpfe', 80-82.

54 Ibidem, 84. Taken from a citation in Wilhelm von Humboldt's 'Ueber die mit dem Königsberger Schulwesen vorzunehmenden Reformen', Wilhelm von Humboldts Werke, vol. 13. Wilhelm von Humboldts Gesammelte Schriften, ed. by Albert Leitzmann (Berlin: De Gruyter, 1920), 259-276, and most of all from the so-called Lithuanian School Plan (Gumbinnen, September 1809), as well as On the Inner and Outer Organization of a Higher Scholarly Institution in Berlin (Berlin, 1810).

55 Hans-Dieter Nägelke, Hochschulbau im Kaiserreich: historische Architektur im Prozess bürgerlicher Konsensbildung (Kiel: Ludwig, 2000), 14.

56 Klaus-Dietrich Gandert, Vom Prinzenpalais zur Humboldt-Universität. Die historische Entwicklung des Universitätsgebäudes in Berlin mit seinen Gartenanlagen und Denkmälern (Berlin: Henschelverlag Kunst und Gesellschaft, 1985).

57 This chapter is based primarily upon my observations in: Gerd-Helge Vogel, 'Von der Pike auf! Vom Gartenlehrling zum akademischen Gärtner und Gartenlehrer in Greifswald und Eldena (1830-1858)', Vom Pommerschen Krummstiel nach Sanssouci: Ferdinand Jühlke (1815-1892). Ein Leben für den Garten(bau), ed. by Gerd-Helge Vogel (Kiel: Ludwig, 2016), 22-33 and the literature noted there in that article. 
played by Albrecht Daniel Thaer (1752-1828). He was born in Celle, Lower Saxony and appointed to the Royal Electoral Agricultural Society of Hanover in 1780. Thaer studied the impressive level of contemporary British agricultural practices, which was seen as a prototype for the entire European continent. He published an influential, three-volume study on the matter: Einleitung zur Kenntniss der englischen Landwirthschaft und ihrer neueren practischen und theoretischen Fortschritte, in Rücksicht auf Vervollkommnung deutscher Landwirthschaft: für denkende Landwirthe und Cameralisten ${ }^{58}$ (Hanover 1798-1804) which helped revolutionize agricultural practices in German-speaking lands. In 1802, as a result of the experience gained from England's higher rates of agricultural productivity, Thaer founded the first German agricultural teaching institute in Celle. It was here that farmers could obtain information on the fundamentals of commercial management and the most recent advances in the natural sciences concerning cultivation (e.g. crop rotation), plant breeding, and fruit/vegetable growing. In 1804, Thaer entered the Prussian civil service and in the same year, thanks to King Friedrich Wilhelm III (1770-1840), he had an opportunity to establish the first German agricultural academy at the manor house of Möglin near Wriezen/Oberbarnim northeast of Berlin, which he opened in 1806. Due to its great success, the institute was re-named in 1809 as the Prussian Royal Academy of Agriculture. And it was at this school, between 1809-1812, that Thaer developed the 'Foundations of Rational Agriculture' and with it the theoretical basis for German agricultural science.

In Prussia, the most desirable result of an academic, agricultural economy was a general increase in profit and return which soon led to the founding of further agricultural academies in various parts of Prussia and other German states. They were all based upon the Möglin Agricultural Academy prototype. Among these belong the establishment, in 1835, of the Royal State Agricultural Academy in Eldena near Greifswald as well as the two founded in 1847 at the manor and estate of Proskau in Silesia (now Prószków, Poland) and at Bonn-Poppelsdorf in the Rhineland.

58 The English translation for Thaer's book title is: An Introduction to the Knowledge of English Agriculture and its Newer Practical and Theoretical Advances with a Consideration of its Application to German Agriculture: For Intelligent Farmers and Cameralists. 
The Agricultural Academy at Eldena was set up to educate and train agricultural economists and civil servants in the fields of administration and finance. It was all in reaction to the Prussian state's change in policy favoring modernization reforms and the extensive, positive achievements indebted to modern, physiocratic production methods, the latter of which had already started during the late $18^{\text {th }}$ century. The application of such progressive scientific methods - advocated by contemporary Enlightenment theories - encouraged agricultural advancements and manifested in the increased yields in grain crops, vegetables, fruit, and livestock breeding. Karl Sigismund vom Stein zum Altenstein (1770-1840), an eager reformist and minister of education and the arts, pushed forward with his ground-breaking reform of the Prussian educational system. He also supported the establishment of further agricultural academies by specifically selecting the estate management at Eldena as a prototypical model for the project. This location was selected in 1813 because, in the Prussian minister's opinion, the Greifswald University's ownership of 15,000 hectares of land (once the Cistercian monastery complex at Eldena subsequently secularized in the $16^{\text {th }}$ century and later given as a gift to the University by the Duke of Pomerania in 1634), served as a most suitable location.

In addition to the location, the choice of this new educational institution's director was decisive for the project's success. Fortunately, it was possible to engage the Jena University professor, agricultural scientist, and economist Friedrich Gottlob Schulze (1795-1860) for the new position. Schulze had a known reputation throughout Germany due to his involvement in the design of a curriculum merging agricultural and political economics with a practical orientation to training. ${ }^{59}$

The new director Schulze drafted plans for the integration and renovation of the existing buildings along with the creation of new ones necessary for the Eldena Academy to be completed before its official opening on 18 May 1835. Instruction began on 25 May 1835 with 22 students using, to some extent, temporary structures. Among others, the curriculum contained courses in state and financial economy, agricultural economy including farming, animal breeding,

59 The theoretical basis for further research and education in agricultural science was established by Friedrich Gottlob Schulze's Ueber Wesen und Studium der Wirthschafts- und Cameralwissenschaften (Jena: Frommann, 1826). 
horticulture, but also agricultural management, forestry as well as an introduction to technological processes in agricultural production (e.g. beer brewing, alcohol distillation, and the production of syrup, sugar, vinegar, and cheese). Brick-making and milling were also part of the students' education. Core subjects in this teaching program were mathematics, botany, and other natural science-related subjects like statistics, agricultural law, and history. Foreign languages (Latin among others) and sport (fencing among others) served as elective subjects.

Since the Eldena manorial estate where the Academy was planned to be housed did not have adequate space for the required academic activities, more had to be created. In 1832, the Greifswald University academic building inspector Carl August Peter Menzel (1803-1845), who had incidentally been a student of the Berlin architect Karl Friedrich Schinkel (1781-1841), ${ }^{60}$ received a commission to design this new school campus. A series of Menzel's preliminary drawings depicts the planned main building, which appeared particularly stately and impressive. Yet, in view of the prerequisites and conditions facing the project, it was almost impossible to immediately execute such an ambitious plan. Schulze had anticipated this eventuality and therefore designed a far more modest, provisional solution. Between 1834 and 1837, a number of simple structures were built in Eldena that fulfilled the most urgent needs for space and ensured courses could be offered to students. But in the summer of 1837, some of the estate's old outbuildings (barns, animal stalls, graneries, etc.) were destroyed by fire, making it imperative that new construction be undertaken in order to continue the Academy's program for academic instruction and farming practice.

When C. A. P. Menzel was given the commission for the Eldena Academy's main building, the development of architecture in West Pomerania received an innovative boost. His design clearly shows the late, neoclassical stylistic idioms of Schinkel's Berlin school. A characteristic example of this architecture from the Academy's founding period is the so-called College Building (Hainstrasse 5). Presumably begun in 1835, the facade today has been somewhat altered from its original appearance, which recalled Schinkel's

60 Before his appointment in Greifswald, Menzel had been active in the Prussian State Construction Commission where Schinkel functioned as director in Berlin. 
influence, in the massive two-storey structure with three large, arcade-like windows and a hipped roof. This original composition itself derived in turn from a previous design done by Menzel in 1834 showing a palace-like, eleven-bay building with a central banqueting room on the main floor. From this plan, however, only the general appearance of the lengthwise roof profile and the articulation of the facade with its eleven windows on the main floor was executed.

F. G. Schulze, as the first director of this newly founded educational institution at Eldena, was greatly admired and esteemed by the students as well as the entire teaching staff due to his scholarly competence and humanitarian character. Despite all this, it did not take long before ever more frequent conflicts arose between Schulze and the university's administrators regarding solutions to a completion of the architectural plans. Sadly, the model of a functional teaching campus, which followed the ideal of an Enlightenment-period university landscape where instruction and research were conducted closely together, would not be fully realized. Since the irreconcilable differences of opinion remained unresolved, the Eldena Academy's founding director saw 'his hope for a successful endeavor thwarted' and in autumn 1838 requested his discharge from the Prussian civil service. After Schulze's departure, his successor Heinrich Wilhelm Pabst (1798-1868) was actually successful during his brief tenure as director at Eldena (1839-1843) in achieving further steps in the organizational and reformative measures required to broaden the curriculum - including the implementation of agricultural excursions for students - so that enrollment increased two-fold. However, in the end, Pabst could do nothing to prevent the Academy's eventual stagnation and decline because Schulze's original plans were never completely and effectively applied.

If one examines Schulze's original pedagogical ideas and the architectural blue-prints for the layout of the Eldena Academy's teaching curriculum as it was applied to the various edifices, it becomes immediately evident not only how well-matched they are in view of the required economic, pedagogical, and aesthetic aspects, but also how successfully the architecture is integrated into the environment's natural topography and still remains within all the necessary parameters.

From an Enlightenment perspective, the English-style garden was both associated with the manor house as an economic base for 
prosperity and professed to be an aesthetic, liberal 'world concept' for society and its utopian goals. During the $18^{\text {th }}$ century, there was a gradual merging of aesthetics with economics, something that logically followed from the Enlightenment principle of reconciling the beautiful and the useful. The result was the ideal of an 'ornamental farm' where agriculture and animal breeding were brought together into a picture of an arcadian landscape garden. Schulze's concept for agricultural prototypes was based upon such ideas. His first, unexecuted plan for the design of an agricultural academy (done prior to 1833) was therefore laid out aesthetically arranged for gardening, farming, and forestry according with such an idealized, ornamental farm. Another plan, which was drafted after the 1837 fire, placed the academy buildings along the so-called 'Elisenstrasse' and reveals a distinct, functional separation between the estate and the facilities used for teaching, yet they all remain in a close, physical proximity to each other. This post-1837 fire plan was approved by the Prussian Ministry of Education and the Arts but, due to a lack of funds, it could only be partially and sporadically realized later in the following years under the director Eduard Baumstark (1807-1889). Although the plan was not fully and immediately completed, it still remained true to the ornamental farm type and its aesthetic ideals. For this reason, the Academy became a beloved destination for the citizens of Greifswald because it was surrounded by an idyllic, arcadian landscape. This beautiful setting included the historic ruin of a Cistercian monastery near the Baltic Sea coast, a landscaped park, and a pleasure-park for Sunday strolling. Thus, artists like Eduard Ludwig Lütke (1801-1850) soon discovered the gorgeous countryside views of Eldena and its environs. Lütke's lithographs helped pave the way for local tourism, especially after the completion of the charming, tree-lined avenue connecting Eldena with the city of Greifswald in 1840-1841. Finally, in 1876, the Academy had to be closed because the agricultural curriculum was no longer being efficiently put into practice so that the quality of education suffered and eventually failed to meet the public's expectations. Regretfully, idealistic philosophies and practical, economic demands could not, in the end, be made compatible with each other. 
Gerd-Helge Vogel: Architecture for Teaching, Learning and Research: Academic Architecture at German Universities in the European Context from the Middle Ages to the Enlightenment Keywords: German universities; Middle Ages; Enlightenment; ARCHITECTURE; EDUCATION IN THE $19^{\text {TH }}$ CENTURY

Gerd-Helge Vogel is an Assistant Professor (Emeritus) at the Zürich University of Applied Arts (ZHdK), Switzerland, University of Greifswald, Germany, and was Visiting Professor at the Estonian Academy of Arts, Tallinn (1999, 2002). He received his PhD in art history at the University of Greifswald (1982) with the dissertation Die Dresdner Bildnismalerei zwischen Retablissement und Restauration and completed his habilitation also at Greifswald (1989) on the theme Der Traum von Batavisch Arcadia. Studien zur Theorie und Praxis in der holländischen Malerei um 1800. He has organized conferences and curated exhibitions in Germany, Switzerland and Poland, and also written or edited over 250 scholarly publications on $18^{\text {th }}$ and $19^{\text {th }}$ century European and German painting, architecture, sculpture, garden history, scientific illustrations, and poster art. He has specialized in the Enlightenment and Romantic periods with a focus on the painters Christian Leberecht Vogel, Carl August Senff, Johann Gustav Grunewald, and the sculptor Joseph Mattersberger among others. Some of his general studies have dealt with the regional art of Saxony, Pomerania, and Estonia, as well as the work of German Impressionists. His most recent publications include: Adam Friedrich Oeser. Götterhimmel und Idylle (2017); Vom Pommerschen Krummstiel nach Sanssouci. Ferdinand Jühlke (1815-1893). Ein Leben für den Garten(bau) (2016). 